\title{
Forum
}

\section{Do Literary Studies Have an Ideology?}

\section{To the Editor:}

Frederick Crews wrote in the May issue of $P M L A$ a brilliant and impassioned plea under this very same title for a literary criticism which will demand that "works be understood, not as transcendent icons and refuges from the world, but as contingent, imperfect expressions of social and mental forces" (p. 428). In the course of the paper, we get an outburst on the iniquities of capitalism which is now in its late stages and growing more repressive year by year. Mr. Crews's strictures against capitalism may be right, and I certainly believe that more scholarship and criticism should be society-and-life-oriented rather than formalistic. However, I do not want to get into a discussion of the justice or injustice of capitalism because I think that this question, though arguable, is finally irrelevant to the matter of whether there is a non-ideological aspect to literature. If we set up ideological standards for our scholarship and criticism, we shall bring upon ourselves the destruction of freedom, ideological quarrels with tests of purity, and the suppression of opposition. If we enter into exclusively ideological evaluations of literature, we shall be entering into a field full of pitfalls. The energy we should devote to the understanding of literature will be expended in quarreling. If ideological purity is sought, we will get censorship and tests of soundness. We shall then be deciding whether a work is in the socialist-realistic tradition or not, or whether it contributes to the advancement of communism or not.

The vast mass of criticism and scholarship in any country is not first-rate, but some of it is. I believe that we find much more first-rate material in the West than in the "socialist" world; and this is so because we have a value in America and the West which Mr. Crews, with his skilled rhetoric, passes over much too quickly. The rhetoric of minimizing our freedom that we find in Mr. Crews's article is most disturbing. Of course, the standard answer to the fact that we have a good deal of freedom to complain and criticize is to point to the oppression of the blacks and the chicanos, Judge Hoffman, the Bobby Seale trial, the students killed at Kent State, etc. However imperfect it is, and it is certainly imperfect, voices (including Mr. Crew's) can be and have been raised in this country on the side of justice, real or assumed, and against ignorance and cruelty. Mr. Crews may dismiss all this in one sentence, but I do not believe the majority of the members of MLA would want to do so. Ask those who have lost this power of criticism if it is so minor a matter. From
Soviet insane asylums they will no doubt want to laugh with us.

The arguments that Mr. Crews brings forward are reductionist in the worst sense of the word. $\mathrm{He}$ is fundamentally reductionist because he wishes to filter down literature to its social and mental causes. Literature, he argues, must be studied in these terms. I myself and many others more qualified have done so over the past thirty years, but it cannot be exclusively studied as such. Professor Erdmann of the University of Jena, as Lincoln Steffens tells us, complained that in his time when it was asked what was man, the answer was, "he was an ape." Explanations of literature as of anything cannot be exclusively given in terms of its antecedents. "All things move," of course, but things have form and structure as well. If form and structure have been overemphasized in the recent past, the answer is not to throw them out. If the cow won't give enough milk, it won't help to turn to the bull for it.

If we can agree that literary studies do have an ideology, we have not succeeded in showing that King Lear is the same work as The Communist Manifesto. They are neither ideologically nor esthetically equal. Everything in a society has ideological implications, but it is the crudest kind of reductionism to think that we have really done much to explain a literary work or literary figures thereby. A principle which explains everything explains nothing. After all, everything in a society is also biologically oriented, but it is not much help to us to learn that Hamlet is not useful in the biological struggle for survival whereas Konrad Lorenz' King Solomon's Ring is. Even Marx recognized the significance of levels, and the major cause of "Left-Wing Communism as an infantile disorder" was, as Lenin saw it, this inability to distinguish various levels of action. Society is made up, as Hegel has taught us, of a variety of forces, events, ideas acting on each other. Some of these may of course be more important and basic than others, difficult as that may be to prove, but to refer to Lenin again, "the revolutionary class in order to fulfil its task must be able to master all forms or sides of social activity without exception."

The other side of the reductionist nature of $\mathrm{Mr}$. Crews's argument is that essentially he denies any autonomy to literature at all. Marx and Engels, as I have said, were prepared to allow for the autonomy of elements in the superstructure. One of their complaints against eighteenth-century materialism was that it was not dialectical, that is, it did not allow for the autonomy of levels. Once society arises from nature, there 
are laws which characterize society alone. Once literature and art arise from society, they too have laws of their own to obey. In other words, there is an autonomous realm to art and literature however firmly they may be rooted in society and psychology. Marx and Engels knew how to pour out their scorn on crude reductionists who refused to see that everything had certain laws pertaining to it alone and that new levels have some self-sufficiency.

Mr. Crews does not seem to allow for any autonomy to literature. All literature is ideological for him. True, but everything is also made up of electrons and protons. There is a difference between things which arise at higher levels. Without some autonomy to new levels there can be nothing differentiated at all. Literature has a social and psychological matrix out of which it has come, and it has social implications, often of the most important sort, but it is not just its own origin-nor its effects. In short, it has its own ä $\rho \epsilon \tau \epsilon$.

If there is some autonomy in the study of literature, if literature has its own structures and rules independent of the matrix out of which it comes, should we not as students of literature stand up for them? What advantage shall we gain in leading the way to the destruction of our subject matter as an autonomous study? If we won't support our subject, who will? It is not enough as human beings to stand for literary values alone, but we must stand for them as well as for human values. Not all human values are political and social. Furthermore, many literary values are human too. They are human because they stress the importance of reason and thought, because they recognize the tragic and comic aspects of the human condition, because they know that formal perfection increases the memorability of human perfection, because wisdom has always been one of their main goals, and finally because they respect accuracy and honesty. Formal aspects should be admired insofar as they help us to attain these ends.

The best is the enemy of the good. In the apocalyptic atmosphere of our time, to repeat this proverb is to guarantee the shutting of ears. We are now in a heady period of pushing for Utopia in a rapid drive, and reminders not to lose what we have in the desire to get to something better are not very welcome. This turmoil is no doubt useful. We have grown intellectually complacent and need to be reminded of our shortcomings. But we are not going to be helped toward our goals by creating tyranny in the name of liberty or by destroying what values we have in the name of higher values. Of course, we must drive on, and $\mathrm{Mr}$. Crews is right to urge us to do so. The MLA must take a part in the changes of our time and would be derelict in its duty if it did not stress that questions other than those of irony and symbolism can be asked of literature. The new art forms related to literature are part of our sub- ject. The social implications of our work need to be explored. The relations of English to other disciplines should be studied. But the danger is that we destroy ourselves. Between the antinomies of action and thought, sensitivity and intellect, anarchy and inquisition, there is a whole range of positions which are worthy of occupying a man's life for good and which unify existence. No account of the failures to reach these ideals should destroy our faith in them. If we must go underground we will go underground, but the torch of humanism should not be allowed to lose its light in a universal holocaust by our throwing more fuel on the fire. We may have to take to the barricades, but before we go, let us at least tell men that there is a better alternative.

Morton W. BLoOMfield

Harvard University

To the Editor:

In his article "Do Literary Studies Have an Ideology?"' (May 1970, 423-28), Frederick Crews casts such a wide net in his attempt to attack monopoly capitalism, the cold war, objective scholarship, as well as current trends in literary criticism, that a one-page rebuttal can discuss only one point. I confine my remarks, therefore, to Professor Crews's plea that our criticism and scholarship should not transmute the real passions of the masters into "formal patterns," but should instead "reject such escapism and demand that works be understood, not as transcendent icons and refuges from the world, but as contingent, imperfect expressions of social and mental forces" (p. 428).

Despite Professor Crews's modish attempt to link formal analyses with "the values of capitalism in its monopoly phase," his argument is similar to that of the didactic critics, or the Christian humanists as Douglas Bush would call them, who for over twenty years have been attacking what were then the New Critics for robbing literature of its moral significance. Of course Professor Crews and his friends on the New Left would find a different significance in the masters than would Douglas Bush and his friends on the Old Right. But both groups would agree that literature is not primarily an art, like music or painting, but primarily expressions ("imperfect" to Professor Crews, but sublime to Douglas Bush) of "social and mental forces." And both left-and right-wing moralists blame formalist criticism for transmuting the moral passion of the writer (whether it be "savage indignation" or Christian humility) into formal patterns of irony and paradox.

One answer to these charges, in brief, is that it is not the critics who have divorced literature from the passions of life, both personal and social, but the artists themselves. For whatever art may be, it is not simply an expression of what we feel in life. Something 